\title{
Die lewe en werk van Karl Barth (1886-1968): 'n Leksikografiese bydrae tot Reformasie 500
}

\begin{abstract}
Author:
Gabriël M.J. (Gafie) van Wyk

Affiliation:

${ }^{1}$ Department of Church History and Polity, Faculty of Theology, University of Pretoria, South Africa

Research Project Registration: Project Leader: W.A. Dreyer (1) Project Number: 77370920

\section{Description:}

Dr Gafie van Wyk is participating in the research project, 'Ecumenical creeds and Confessions', directed by Dr Wim Dreyer, Department of Church History and Church Polity, Faculty of Theology, University of Pretoria.
\end{abstract}

\section{Corresponding author:}

Gafie van Wyk,

gafievw@mweb.co.za

Dates:

Received: 07 Apr. 2017

Accepted: 05 July 2017

Published: 31 Aug. 2017

How to cite this article: Van Wyk, G.M.J., 2017, 'Die lewe en werk van Karl Barth (1886-1968):'n Leksikografiese bydrae tot Reformasie 500', HTS Teologiese Studies/ Theological Studies 73(1), a4592. https://doi.org/ 10.4102/hts.v73i1.4592

\section{Copyright:}

(c) 2017. The Authors. Licensee: AOSIS. This work is licensed under the Creative Commons Attribution License.

\section{Read online:}

Scan this QR
code with your
smart phone or
mobile device
to read online.

Karl Barth was a leading thinker within an influential theological direction that arose in Europe after the First World War, known as dialectical theology. Comprehensive introductions to the life and work of Barth in the South African theological journals, written in Afrikaans, either does not exist, or are difficult to trace for the Afrikaans readership. This article on Barth aims to fill the gap by offering a lexicographical contribution on the life and work of Barth. The focus of this article is on Barth as a Reformed theologian. The theme of the New Testament and systematic theology is essentially the same, namely to explain the concept of Christian self-understanding as an eschatological event in which faith is expressed for the sake of faith in God and only in God. Barth explained the same theological concepts with his theology as those that were explained by the church reformers of the 16th century, but under radically new circumstances. The so-called modern and postmodern people of our time not only broke ties with the past, but in the process they also lost their ability for using historical-critical patterns of thought that tries to bridge historical distances, and therefore, sacrificed all efforts to think systematically on the altar of relativism. We can learn from Barth what systematic reformed theology really is.

\section{Inleiding}

Karl Barth was 'n leidende denker binne 'n invloedryke Reformatoriese teologiese rigting wat in Europa na die Eerste Wêreldoorlog ontstaan het en waarna soms as die dialektiese teologie verwys word (Pannenberg 1958:168). Ondanks grondige saaklike verskille oor teologiese kwessies ${ }^{1}$ tussen Barth en 'n tydgenoot van hom, Rudolf Bultmann, het hulle lewenslank 'n vriendskaplike verhouding met mekaar in stand gehou (Jaspert 1994:xii). Uitvoerige korrespondensie tussen dié twee, wat tussen 1911 en 1966 gevoer is, is sowel 'n belangrike teologiese nalatenskap as 'n getuienis van die vriendskap tussen Barth en Bultmann (Jaspert 1994:1-203). Verskeie oorsigtelike artikels oor die lewe en werk van dié twee teoloë is in Engels, Duits en ander Europese tale op die Internet of in druk beskikbaar. Inligting uit die databasis van Sabinet, SA ePublications (https://journals. co.za) dui daarop dat omvattende oorsigtelike inligting oor die lewe en werk van Barth en Bultmann in die Suid-Afrikaanse teologiese tydskrifte, in Afrikaans geskryf, óf nie bestaan nie, óf moeilik opspoorbaar is vir die Afrikaanse leserspubliek. Hierdie artikel oor die lewe en werk van Barth, gelees saam met een oor die lewe en werk van Bultmann, wil dié leemte vul deur in Afrikaans 'n leksikografiese bydrae te lewer oor die twee toonaangewendste teoloë van die sogenaamde dialektiese teologie. Die fokus in die twee artikels is op Barth en Bultmann as Reformatoriese teoloë - Barth as verteenwoordigend van gereformeerde denke en Bultmann as 'n Lutherse teoloog.

\section{Die lewe van Karl Barth}

Karl Barth (1886-1968) word soms aangeprys as die belangrikste teoloog van die 20ste eeu. Sulke aanprysings is aanvegbaar, want hoe sou die belang van Barth in vergelyking met dié van ander belangrike teoloë van die 20ste eeu, byvoorbeeld Bultmann en Ebeling, so gou na sy afsterwe bepaal kon word? Hoe dit ook al sy, hy het enorme invloed op die teologie en die Westerse kultuur uitgeoefen ver buite die grense van Switserland en Duitsland. Daarom sou dit nie onvanpas wees nie om hom in een asem te noem met die name van byvoorbeeld Thomas Aquinas, Johannes Calvyn en Friedrich Schleiermacher as een van die toonaangewendste denkers in die geskiedenis van die Christelike tradisie. Barth het met sy teologie nuwe rigting aangedui in 'n kritieke stadium in die geskiedenis toe die teologie wêreldwyd getaan het tussen die ekstreme van die liberale

1.In der Beziehung zwischen Karl Barth und Rudolf Bultmann (1884-1976) wechselten Phasen der Nähe und der Distanz, eines partiellen theologischen Einverständnisses und eines schier unüberbrückbaren Nichtverstehens, einander ab (Hammann 2016:96). Nadat Hammann (2016:96-101)' $n$ kronologiese oorsig oor die raakpunte en verskille in die teologiese ontwikkeling van Barth en Bultmann se denke gegee het, kom hy tot'n gevolgtrekking oor die wese van die saak: Barth suchte auf Grund der Wirklichkeit der Offenbarung die denke gegee het, kom hy tot'n gevolgtrekking oor die wese van die saak: Barth suchte auf Grund der Wirklichkeit der Offenbarung die
in der souveränen Freiheit Gottes begründete Möglichkeit der Offenbarung trinitätstheologisch nachzuvollziehen. Deshalb wählte er die Analogie zu der diesem Anliegen adäquaten Denkform. Demgegenüber begriff Bultmann die Offenbarung als das eschatologische Geschehen, das in paradoxer Weise mit einem historischen Ereignis - der Geschichte Jesu - identisch ist. Deshalb gab er als Kriterium der Wahrheit theologischer Aussagen deren anthropologische Relevanz aus (Hammann 2016:101). 
teologie aan die een kant, waar teologie neutrale godsdienswetenskap geword het (Pfleiderer 2016:59-64), en die biblistiese ortodokse teologie aan die ander kant, waar teologie ingeperk is binne ' $n$ ontoegeeflike leersisteem waarin teologie versmoor is tot die handhawing van 'n lewelose tradisionalisme (Freudenberg 2016:132-137). ${ }^{2}$ Barth het teologie herdefinieer as sistematiese teologie wat opgewasse is vir die uitdagings en die realiteite van die 20ste eeu (Freudenberg 2016:137). As die primêre outeur van die Teologiese Verklaring van Barmen, het hy uitgemunt as die intellektuele leier van die Belydende Kerk in Duitsland die kerklike groepering wat weerstand gebied het teen die Derde Ryk van Hitler (Greschat 2016b:430-437). Die meeste van sy boeke is in amper elke Europese taal vertaal, sowel as in Russies, Japannees, Chinees en Koreaans.

Karl Barth is op 10 Mei 1886 in Basel, Switserland, gebore as die oudste kind van Fritz Barth, 'n Reformatoriese Switserse predikant (en latere professor in teologie), en Anna Katharina (Sartorius) Barth (Bush 1993:13, 2016a:14; Jüngel 1982a:23). Uit die huwelik is vyf kinders gebore. Karl het twee jonger broers gehad, Peter (wat 'n predikant geword het) en Heinrich (wat ' $n$ professor in filosofie geword het), en twee susters, Katharina en Gertrud (Busch 1993:23; 2016a:15). Sy ouma aan moederskant was familie van die bekende historikus Jacob Burckhardt (Busch 2016a:14). Barth het saam met sy broers en susters die meeste van sy kinderjare in Bern, die hoofstad van Switserland, deurgebring nadat sy vader in 1891 by die universiteit as professor in Nuwe Testament en vroeë kerkgeskiedenis aangestel is (Busch 1993:23, 14-15). Volgens oorlewering was Karl as kind glo 'n rakker wat nie daarvan gehou het om skool by te woon nie. Hy was gereeld in die moeilikheid oor kattekwaad wat hy en sy 'bende' by die skool en in die woonbuurt aangevang het (Zellweger 2017:1). In Oktober 1904 volg hy in die voetspore van sy vader deur teologie te begin studeer aan die Universiteit van Bern (Busch 2016b:18). Hy sit sy studies later in Duitsland voort by die universiteite van Tübingen (1907) en Marburg (1908) (Busch 1993:45-71; 2016b:20-22). Onder Barth se dosente tel Adolf von Harnack, een van die vernaamste eksponente van die liberale teologie in Duitsland, en Wilhelm Herrmann, 'n navolger van die Neokantianisme van Albrecht Ritschl, asook Adolf Schlatter, Wilhelm Heitmüller, en die filosowe Hermann Cohen en Paul Natorp (Busch 2016b:20 21; Jüngel 1982a:24-25).

Na 'n kort proponentskap in Berner Jura ('n Franssprekende woongebied in Bern), gaan Karl Barth weer na Marburg, om Immanuel Kant en Friedrich Schleiermacher te bestudeer. Kant en Schleiermacher se denke het die karakter van die Protestantse teologie van die 19 de eeu grootliks bepaal. In hierdie tyd werk hy as subredakteur van die Christliche Welt,

2.Darin spiegeln sich seine Hochschätzung der Konfessionalität und zugleich seine Ablehnung eines selbstgenügsamen Konfessionalismus, der sich über andere Konfessionen erhebt. Es gehört zum Selbstverständnis von Barths Theologie, dass Konfessionen erhebt. Es gehört zum Selbstverständnis von Barths Theologie, dass Wahrheitserkenntnis nicht exklusiv in einer Konfession beheimatet ist, sondern sich im Diskurs der Konfessionen ereignet. Nach Barth wird die reformierte Theologie ihrer Aufgabe gerecht, wenn sie nach ihrem Dienst für die Gegenwart und für die anderen Konfessionen fragt. Konfessionelle Identitat lasst sich nicht allein im Blick auf die Historie oder durch Selbstbehauptung und Abgrenzung sicherstellen, sondern muss fortlaufend neu und im Bewusstsein ihrer Vorläufigkeit gewonnen werden (Freudenberg 2016:137). 'n Protestantse tydskrif wat deur Martin Rade uitgegee is (Busch 2016b:20).

$\mathrm{Na}$ sy bevestiging in die amp is Barth hulppredikant in Genève van 1909 tot 1911 (Busch 1993:67-71, 20-21), en daarna predikant in die klein dorpie Safenwil van 1911 tot 1921 (Busch 1993:72-138, 22-26). In 1913 tree hy in die huwelik met Nelly Hoffman, wat by hom in Genève gekatkiseer het. Uit die huwelik word vyf kinders gebore Franziska, Markus, Christoph, Matthias en Hans (Busch 2016b:23).

In Safenwil was Karl Barth die predikant van 'n klein plattelandse werkersklasgemeente. Hy het hom in die gemeenskap beywer om die opvoedingspeil van die mense te bevorder, en hy het geveg vir die sosiale regte van sy gemeenskap (Greschat 2016a:154). Dit is hier waar Barth die eerste uitgawe van sy kommentaar op Paulus se Brief aan die Romeine geskryf het - 'n werk wat die hoeksteen gevorm het van al sy teologiese werk wat later sou volg, en wat internasionaal soveel aandag getrek het dat hy op grond daarvan by die Universiteit van Göttingen, in Duitsland, as professor aangestel sou word, ondanks die feit dat hy nie 'n doktorsgraad in die teologie gehad het nie (Busch 1993:72138; 2016c:22-26).

In 1925 ontmoet Barth vir Charlotte von Kirschbaum, met die bynaam Lollo, wat mettertyd sy lewenslange assistent en vertroueling sou word (Jüngel 1982a:26; Stoevesandt 2016:5458). Gedurende Oktober 1929 trek Von Kirschbaum by die Barth-familie se woonhuis in (Stoevesandt 2016:56). Dit was die begin van 'n 35 jaar lange huishoudelike reëling tussen Barth, sy vrou Nelly en Von Kirschbaum, wat geweldige spanning geplaas het op almal wat in die driehoekige verhouding betrokke was, baie wenkbroue in die gemeenskap laat lig het en kritiek van Barth se kollegas ontlok het. Von Kirschbaum was 'n teoloog in eie reg. Sommige biograwe meen dat beduidende dele van Barth se teologiese werk, soos verskeie van die langer ekskursies in die Kirchliche Dogmatik, eintlik Von Kirschbaum se werk is ${ }^{3}$ en dat sy as assistent deur Barth misbruik is.

Van 1921 tot 1925 was Barth dosent in gereformeerde teologie in Göttingen, van 1925 tot 1930 was hy professor vir Dogmatiek en Nuwe-Testamentiese Eksegese in Münster, en van 1930 tot 1935 was hy professor vir Sistematiese Teologie in Bonn (Beintker 2016a:206; 2016d:235; Jüngel 1982a:26; Smend 2016:31-37). In Bonn begin hy werk aan die Kirchliche Dogmatik, sy magnum opus, wat nooit voltooi is nie en wat meer as 9300 bladsye in 13 volumes beslaan (Jüngel 1982a:26).

3.In die Vorwort van KDIV/4 verwys Barth terugskouend na Charlotte von Kirschbaum as sy onontbeerlike en getroue medewerker wat ' $\mathrm{n}$ onmeetlike aandeel aan die ontstaan ) d die 1967:VIII). Stoevesandt plaas die opmerking van Barth in perspektief: Die Lebensgemeinschaft wurde, wie ihr durch die Lekture von Schriften Barths de Boden bereitet war, mehr und mehr und dann bleibend eine Arbeitsgemeinschaft. Barth legte Wert darauf, dass von Kirschbaum seine Manuskripte mitlas, und wartete gespannt auf ihre Reaktion, ja ihr Urteil (Stoevesandt 2016:56).

Dass von Kirschbaum auf die endgültige Formulierung Einfluss genommen oder gar einzelne Teile der Exkurse selbst verfasst hätte, dürfte eine (verbreitete) Legende sein die der Verfasser dieses Artikels aus späterem eigenem Erleben als Mitbewohner des Barthschen Hauses 1954/55 für ausgeschlossen hält (zu einer partiellen Ausnahme s. u. im Abschnitt über von Kirschbaums selbständige Arbeit) (Stoevesandt 2016: 56). 
Karl Barth het radikale weerstand gebied teen die NasionaalSosialisme - selfs nog voordat Adolf Hitler in 1933 aan bewind gekom het in Duitsland. Hy was veral gekant teen die planne van die Nazi's om die Duitse Kerk in te span om hulle rassistiese agenda te legitimeer en te propageer. In Junie 1933 publiseer Barth die eerste uitgawe van die tydskrif Theologische Existenz heute, wat wyd ontvang is as 'n wekroep teen die NasionaalSosialisme (Greschat 2016b:431). Die ideologiese en organisatoriese kaping van die Evangeliese Kerk in Duitsland deur die Nasionaal-Sosialiste het 'n minderheid in opstand gebring, wat aanleiding gegee het tot die stigting van die Belydende Kerk (Bekennenden Kirche). Met die hulp van Hans Asmussen en Thomas Breit stel Barth die konsepdokument van die Teologiese Verklaring van Barmen op, wat op die eerste Belydenissinode van 31 Mei 1934 deur 139 afgevaardigdes uit 18 Landeskirchen eenparig aanvaar word (Greschat 2016b:432; Herwig 2016:145). Barth was sonder enige twyfel die primêre outeur van die Teologiese Verklaring van Barmen. Die verklaring het die teologiese basis gevorm vir weerstand teen die ideologiese kaping van die kerk deur die staat. Dit bied 'n sistematiese uiteensetting van die basiese menseregte. Barth het die verklaring persoonlik aan Hitler gestuur (Jüngel 1982a:26).

In 1934 word Barth onthef van sy posisie as professor in Bonn en word hy gedwing om Duitsland te verlaat omdat hy geweier het om die eed van getrouheid teenoor Adolf Hitler af te lê. Hy sou bereid wees om dit te doen, indien die klousule tot die mate dat ek as in verantwoordelike Protestantse Christen daartoe in staat is, ingevoeg sou word (Dölecke 2016:471; Jüngel 1982a:26). Die relevante outoriteite in Basel, Switserland, het hom dadelik as professor in Sistematiese Teologie by die Universiteit van Basel aangestel, van waar hy sedert 1935 voortgegaan het om die belange van die Belydende Kerk, die Jode en ander onderdrukte mense te dien. Barth het in diens van die Universiteit van Basel gebly tot met sy aftrede in 1962 (Dölecke 2016:471; Jüngel 1982a:27). Gedurende 1946 en 1947 het Barth wel weer as gasdosent teruggekeer na Bonn vir drie reekse lesings (Dölecke 2016:472).

Nadat die Tweede Wêreldoorlog tot 'n einde gekom het, het Barth 'n belangrike bydrae gelewer om die Duitse Kerk tot die belydenis van skuld te bring en dié kerk met ander kerke in die wêreld te versoen. In 1948 is hy gevra om die hoofrede te lewer by die eerste vergadering van die Wêreldraad van Kerke in Amsterdam, Nederland (Dölecke 2016:473; Herwig 2016:146). Hy het ook 'n vername rol gespeel in die voorbereidings van die tweede byeenkoms van dié Raad in 1954 in Evanston, Illinois, in die VSA (Herwig 2016:146-147).

In die 1950's het Barth kontroversie ontlok met sy protes teen kernbewapening en sy pogings om, in solidariteit met Christene agter die yster gordyn, hom te beywer vir die beëindiging van die koue oorlog tussen die Weste en die Ooste (Greschat 2016a:157; Jüngel 1982a:27).

In 1962, kort na sy aftrede, besoek Barth die VSA op 75 -jarige ouderdom vir die eerste keer. Die besoek is aangemoedig deur sy seun Markus wat professor in Nuwe Testament by die Universiteit van Chicago was. Karl Barth het vir sewe weke deur die VSA gereis en lesings aangebied by Princeton Theological Seminary, the University of Chicago, Union Theological Seminary en San Francisco Theological Seminary. In Princeton het hy die dapper Martin Luther King Jr ontmoet. Na Barth se oordeel was dié ontmoeting te kort. Die feit dat hy gedurende daardie jaar ook op die voorblad van Time Magazine verskyn het, dui aan dat hy invloed op die hoofstroom Amerikaanse godsdienstige kultuur uitgeoefen het (Dölecke 2016:473).

Karl Barth sterf op 10 Desember 1968 in sy huis in Bruderholzlaan, in Basel (Dölecke 2016:474; Jüngel 1982a: 27-28).

\section{Enkele belangrike momente in Barth se lewe ${ }^{4}$}

1886 Gebore op 10 Mei in Basel, Switserland.

1891 Die Barth-gesin verhuis na Bern.

Aflegging van geloofsbelydenis in Bern by ds Robert Aeschbacher.

1904-1908 Studeer Reformatoriese teologie in Bern, Marburg, Tübingen en Berlyn.

1908 Proponent in Berner Jura ('n Franssprekende gebied in Bern)

Subredakteur vir die Protestantse tydskrif Christliche Welt.

1909-1911 Hulpprediker in die Duitssprekende gemeente van Genève.

1911 Bevestiging as predikant in die dorpie Safenwil op 09 Julie.

1911-1921 Predikant in Safenwil.

1913 Tree in die huwelik met Nelly Hoffmann.

1921 Professor aan die Universiteit van Göttingen in Duitsland.

1924 Ontmoet Charlotte von Kirschbaum wat later sy assistent en vertroueling sou word.

1925-1930 Professor in Dogmatiek en Nuwe-Testamentiese Eksegese in Münster.

1929 Von Kirschbaum trek by die Barth-huisgesin in.

1930-1935 Professor in Sistematiese Teologie in Bonn.

$1934 \quad$ Neem leiding met die opstel van die Teologiese Verklaring van Barmen.

1935 Word onthef as professor in Bonn en gedwing om Duitsland te verlaat nadat hy weier om onvoorwaardelik'n eed van getrouheid teenoor Adolf Hitler af te lê.

1935-1962 Professor in Sistematiese Teologie aan die Universiteit van Basel.

1962 Emeritaat

Besoek die VSA en bied lesings aan in Princeton, Chicago en San Francisco.

In Princeton ontmoet hy Martin Luther King Jr.

Hy verskyn op die voorblad van Time Magazine, wat sy invloed op die hoofstroom Amerikaanse kultuur bevestig.

1968 Sterf op 10 Desember in sy huis in Basel.

4.Vir ' $n$ omvattende tydtafel oor die lewe en werk van Karl Barth, kyk Dölecke 2016:469-474. 


\section{Barth is op die volgende maniere vereer}

1950 Lid van die American Academy of Arts and Sciences.

1952 Britse orde van verdienste vir vrede.

1963 Sonning-prys van die Universiteit van Kopenhagen.

1966 Eresenator van die Universiteit van Bonn.

1968 Sigmund-Freud-Preis für wissenschaftliche Prosa der Akademie für Sprache und Dichtung in Darmstadt.

1968 Lid van die Académie des Sciences Morales et Politiques de l'Institut de France.

\section{Barth het eredoktorsgrade ontvang van die volgende universiteite}

Münster (1922), Glasgow (1930), Utrecht (1936), Aberdeen (1937), Oxford (1938), Boedapest (1954), Edinburgh (1956), Genève (1959), Straßburg (1959), Chicago (1962), Parys (1963).

\section{Barth se bydrae tot die Reformatoriese teologie Oorsig}

Jüngel (1982a:28) beskryf Barth se teologie as sisteemvyandig. Sy teologie word in beweging gebring en in beweging gehou deur sake voortdurend denkend te korrigeer. ${ }^{5}$ Dit beteken om voortdurend weer met die aanvang te begin. Vir Barth het die aanvang, waarmee alle teologie weer en weer begin, 'n naam, naamlik Jesus Christus (Jüngel 1982b:18). Barth se teologie is in die eerste plek daarom ook teologie van die Woord van God (Genest 2016a:29; 2016b:241; Hüttenhoff 2016:216-217; Korsch 2016a:276-281; Maurer 2016:166). Toe Barth aan die Kirchliche Dogmatik begin werk het (in die 1920's en 1930's), het hy gereeld benadruk dat die Woord van God aanspreking is - God as persoon praat met menslike persone om ons aan te spreek en op só'n wyse met ons oor onsself te praat (Weber 1967:17). Sy teologie as Teologie van die Woord is ook dialektiese teologie - omdat God se Woord altyd net indirek beskikbaar is vir diegene wat as menslike hoorders aangespreek word (Beintker 2016b:200-201). Ons ontvang die Woord van God as mense in een van drie vorms: die vleesgeworde Woord, Jesus Christus; die woorde van die profete en apostels (soos dit onder andere in die Heilige Skrif neerslag gevind het); en die woorde van diegene wat die evangelie verkondig. Die onderskeie vorms waarin ons die openbaring van God ontvang (selfs ook die mens Jesus), word nie self vergoddelik nie en moet van God onderskei word (Maurer 2016:166). Barth tref daarom konsekwent 'n onderskeid tussen die openbaring van God en die verskillende vorms waarin ons die openbaring ontvang (McCormack 2016:248). Anders gestel, 'n mens mag nooit die openbaring van God objektiveer tot iets wat direk vir mense toeganklik is deur sensoriese aktiwiteite (soos om te hoor of te lees) nie (Beintker 2016b:200-201). 'n Mens kan God nie leer ken deur kennis te neem van inligting oor Hom nie. God laat Hom ken op wyses wat Hy self kies. God openbaar Homself vanuit sy verborgenheid, wat 'n funksie van die modaliteit van sy selfopenbaring is. Openbaring kan nie deur mense besit word nie. Dit is eenvoudig nie binne die beheer of die kontrole van mense nie (Van der Kooi 2016b:196, 198). Dit kan daarom ook nie deur mense met die oog op menslike doeleindes ingespan word nie. Barth het reg deur sy lewe hierdie opvatting gehandhaaf. Dit was 'n wyse waarop hy die vryheid van God eerbiedig en gedien het (Beintker 2016b:201).

Karl Barth was 'n besondere produktiewe skrywer, wat in sy leeftyd meer as 600 werke gepubliseer het. Baie van sy gepubliseerde werk het verband gehou met sy akademiese navorsing en het tot sy status as een van die toonaangewendste denkers van die 20ste eeu en van die Christelike tradisie bygedra. Sy werk het internasionaal aandag getrek en sy bydrae tot die teologiese literatuur is substansieel.

\section{Der Römerbrief}

In 1916, toe Barth nog predikant in Safenwil was, het hy begin werk aan sy kommentaar op Paulus se Brief aan die Romeine. Dit word in 1919 gepubliseer met die titel Der Römerbrief (Van der Kooi 2016a:189-195). In 1922 word die tweede uitgawe van die boek gepubliseer, wat eintlik 'n nuut geskryfde boek was (Van der Kooi 2016b:195-200). Die twee kommentare het dadelik die aandag getrek as gevolg van die ongewone benadering wat Barth gevolg het. Sy Bybelse en dialektiese benadering was 'n openlike aanval op die liberale benadering tot teologie wat in sy tyd hoogty gevier het (Van der Kooi 2016a:190). Barth weerspreek die liberale teologie wat die Bybel verstaan het as niks meer nie as 'n versameling van berigte oor menslike religieuse ervarings. Hy is daarom ook nie soos die liberale teoloë van sy tyd net geïnteresseer in die persoonlikheid van die historiese Jesus nie. In sy kommentaar redeneer Barth dat God se aansprake op die mense en die uitdagings wat $\mathrm{Hy}$ aan hulle rig, alle pogings die nek inslaan wat God gelyk wil stel aan kultuur, menslike prestasies of menslike besit (Van der Kooi 2016a:190, 193). In die Skrif gaan dit oor God se gedagtes oor die mense en nie oor mense se gedagtes oor God nie.

Karl Barth se kommentaar het internasionaal aandag getrek. Dit het lojale ondersteuners vir sy saak gewerf, maar ook vyande vir hom gemaak. In die Duitssprekende wêreld moes teoloë hulle eenvoudig ten opsigte van die nuwe dialektiese teologie posisioneer. Dit was op grond van dié kommentaar dat Barth in 1921 by die Universiteit van Göttingen in Duitsland, as professor aangestel is, ondanks die feit dat hy nie'n doktorsgraad gehad het nie (Dölecke 2016:470).

\section{Kirchliche Dogmatik}

Helmut Gollwitzer (1976:7) meen Barth se teologie, soos wat dit in die Kirchliche Dogmatik neerslag gevind het, is mooi - nie alleen omdat Barth goed skryf nie, maar veral omdat hy daarin slaag om hartstog en saaklikheid te verbind in sy werk. Karl Barth het die werk aan die 
Kirchliche Dogmatik begin toe hy professor in Bonn was. Dié reeks wat oor 'n tydperk van 36 jaar ontstaan het, sou Barth se belangrikste werk word. Dit is nooit voltooi nie, al beslaan dit meer as 9300 bladsye in 13 volumes. Die boeke is tussen 1932 en 1967 gepubliseer. Die oogmerk van die reeks is om 'n omvattende kritiese oorsig te bied van die interpretasie van die evangelie van God se genade gedurende die eerste 20 eeue na Christus. Vier oorkoepelende temas word in die werk bespreek, naamlik openbaring, God, skepping en versoening (Jüngel 1982a:47-58; McCormack 2016:250-251).

Hoewel die Kirchliche Dogmatik sistematies voorkom, moet dit altyd in gedagte gehou word dat die werk uit voorlesings ontstaan het en daarom nie 'n dogmatiese sisteem aanbied nie. Die werk is verder die vrug van 'n denker wat ten nouste by die politieke en kulturele lewe van Europa betrokke was sodat dit altyd direkte kontekstuele relevansie gehad het. Formeel word die Kirchliche Dogmatik in vier bande gestruktureer. Band I, 1-2 handel oor die leer oor God se Woord, band II, 1-2 handel oor die leer van God, Band III, 1-4 oor die skeppingsleer en band IV, 1-4 oor die versoeningsleer. Die laaste deel is 'n fragment oor die doop. Barth volg in breë trekke die tradisionele loci communes in die strukturering van die werk, maar wyk in drie opsigte daarvan af. (1) Met sy leer oor die Woord van God word die tradisionele prolegomena reeds deel van die saaklike inhoud van die werk. (2) Anders as by die protestantse ortodoksie vorm die uitverkiesingsleer nie langer die vertrekpunt om oor die dade van God te skryf nie. Die leer oor God vervul by Barth dié funksie. (3) Met die vierde band van die Kirchliche Dogmatik hersien Barth nie alleen sy eie teologie grondig nie, maar ontwerp hy ook 'n nuwe argitektuur vir die versoeningsleer (McCormack 2016:250-251).

\section{'n Seleksie van Barth se belangrikste publikasies ${ }^{6}$}

1919

1919

1922

1924

1925

1927

1931

1932

1932-196

1934

1935

1938

1938-1945 Eine Schweizer Stimme. Politische Aufsätze und Briefe.

\section{Barth se nalatenskap}

Eberhard Jüngel (1982a:58-59) het 35 jaar gelede die waarneming gemaak dat Barth se dogmatiese teologie net geringe invloed op die Protestantse teologie gehad het, terwyl dit toenemend betekenis kry in Rooms-Katolieke kringe en binne die ekumeniese beweging. Met sy vroeëre bydraes tot die dialektiese teologie en die indirekte invloed wat hy via die Teologiese Verklaring van Barmen op die Protestantse teologie uitgeoefen het, staan sake egter anders. Barth se bydrae om die liberale teologie in Duitsland te onttroon en die evangeliese teologie in 'n nuwe rigting te stuur, staan bo alle twyfel. Die afgelope aantal jare is die invloed en resepsie van Barth se teologie in detail nagevors. Die gesaghebbende Barth Handbuch, wat in 2016 onder redaksie van Michael Beintker verskyn het, onderskei die volgende fases in die resepsie van Barth se werk:

- In die 1920's (Korsch 2016b:424-430).

- In konfrontasie met die Nationalsosialisme (Greschat 2016b:430-437).

- Tydens die Tweede Wêreldoorlog en kort daarna (Zocher 2016:437-444).

- In die bloeityd van Bultmann se teologie (Körtner 2016:444-451).

- Tydens die 1970's (Holtmann 2016:451-457).

- Aan die einde van die twintigste eeu (Van der Kooi 2016c:457-464).

- Aan die begin van die een en twintigste eeu (Beintker 2016e:464-468).

Die omvang van die Barthresepsie in 'n relatiewe kort tyd, dui duidelik daarop dat die enorme invloed van Barth op die teologie nie onderskat kan word nie.

Verskeie Hervormde predikante tipeer hulle eie teologiese posisionering graag as Barthiaans. Dié tipering was veral in die mode gedurende die laaste helfte van die 1900's. By nadere ondersoek blyk dit gou dat die selftipering Barthiaans in die meeste gevalle nie in die streng sin van die woord opgeneem moet word nie, want dit word eintlik net gebruik om vaagweg aan te dui dat die betrokkenes naby aan die dialektiese tradisie wil staan om hulle sodoende 
van die liberale een af te grens. In die meeste van hierdie gevalle speel die dialektiese metode van analogiese denke nie eintlik enige rol in die teologie van die aanspraakmakers op die Barthiaanse tipering van hulle eie posisies nie, maar gaan dit eerder vir hulle oor 'n affiniteit vir algemene begrippe soos die Gans Andere, openbaring en ontmoeting wat as sleutelbegrippe in hulle teologie ingespan word. Die polities-kritiese gerigtheid van Barth se teologiese benadering het nooit wesentlike invloed op die Hervormde teologie in Suid-Afrika uitgeoefen nie.

\section{Erkenning \\ Mededingende belange}

Die outeur verklaar dat hy geen finansiële of persoonlike verbintenis het met enige party wat hom nadelig kon beïnloed het in die skryf van hierdie artikel nie.

\section{Literatuurverwysings}

Barth, K., 1967, Die Kirchliche Dogmatik, Band IV/4: Die Lehre von der Versöhnung, Evangelischer Verlag, Zollikon-Zürich.

Beintker, M., 2016a, 'Der Dialektiker als Dogmatiker', in M. Beintker (Hg.), Barth Handbuch, S. 206-211, J.C.B. Mohr (Paul Siebeck), Tübingen.

Beintker, M., 2016b, 'Dialektische Theologie', in M. Beintker (Hg.), Barth Handbuch, S. 200-206, J.C.B. Mohr (Paul Siebeck), Tübingen.

Beintker, M., 2016c, 'Quellen-und Literaturverzeichnis', in M. Beintker (Hg.), Barth Handbuch, S. 232-237, J.C.B. Mohr (Paul Siebeck), Tübingen.

Beintker, M., 2016d, 'Resümee: Periodisierung des Barthschen Denkens', in M Beintker (Hg.), Barth Handbuch, S. 232-237, J.C.B. Mohr (Paul Siebeck), Tübingen.

Beintker, M., 2016e, 'Wirkung und Rezeption. Am Beginn des 21. Jahrhunderts', in M. Beintker (Hg.), Barth Handbuch, S. 464-468, J.C.B. Mohr (Paul Siebeck), Tübingen.

Busch, E., 1993, Karl Barths Lebenslauf. Nach seinen Briefen und autobiographischen Texten, Gütersloher Verlagshaus, (Gerd Mohn) Gütersloh.

Busch, E., 2016a, 'Elternhaus und Familie', in M. Beintker (Hg.), Barth Handbuch, S. 14-18, J.C.B. Mohr (Paul Siebeck), Tübingen.

Busch, E., 2016b, 'Lehrjahre', in M. Beintker (Hg.), Barth Handbuch, S. 18-22, J.C.B. Mohr (Paul Siebeck), Tübingen.

Busch, E., 2016c, 'Pfarrer', in M. Beintker (Hg.), Barth Handbuch, S. 22-27, J.C.B. Mohr (Paul Siebeck), Tübingen.

Dölecke, A., 2016, 'Zeittafel zu Leben und Werk', in M. Beintker (Hg.), Barth Handbuch, S. 469-474, J.C.B. Mohr (Paul Siebeck), Tübingen.

Freudenberg, M., 2016, 'Barth und die Reformierten', in M. Beintker (Hg.), Barth Handbuch, S. 132-137, J.C.B. Mohr (Paul Siebeck), Tübingen.

Genest, H., 2016a, 'Exeget und Prediger', in M. Beintker (Hg.), Barth Handbuch, S. 27-31, J.C.B. Mohr (Paul Siebeck), Tübingen.

Genest, H., 2016b, 'Predigten', in M. Beintker (Hg.), Barth Handbuch, S. 237-242, J.C.B. Mohr (Paul Siebeck), Tübingen.
Gollwitzer, H., 1976, 'Einleitung', in H. Gollwitzer (Hg.) Kirchliche Dogmatik. Ausgewählt und eingeleitet von Helmut Gollwitzer, 3. Aufl., S. 7-38, Gütersloher Verlagshaus, (Gerd Mohn) Gütersloh.

Greschat, M., 2016a, 'Barth und die Politik', in M. Beintker (Hg.), Barth Handbuch, S. 153-158, J.C.B. Mohr (Paul Siebeck), Tübingen.

Greschat, M., 2016b, 'Wirkung und Rezeption. In der Auseinandersetzung mit dem Nationalsozialismus', in M. Beintker (Hg.), Barth Handbuch, S. 430-437, J.C.B. Mohr (Paul Siebeck), Tübingen.

Hammann, K., 2016, 'Barth und Bultmann', in M. Beintker (Hg.), Barth Handbuch, S. 96-101, J.C.B. Mohr (Paul Siebeck), Tübingen.

Herwig, T., 2016, 'Barth und die Ökumene', in M. Beintker (Hg.), Barth Handbuch, S. 143-148, J.C.B. Mohr (Paul Siebeck), Tübingen.

Holtmann, S., 2016, 'Wirkung und Rezeption. In den Paradigmenwechseln der 1970er Jahre', in M. Beintker (Hg.), Barth Handbuch, S. 451-457, J.C.B. Mohr (Paul Siebeck), Tübingen.

Hüttenhoff, M., 2016 'Theologische Existenz heute', in M. Beintker (Hg.), Barth Handbuch, S. 216-221, J.C.B. Mohr (Paul Siebeck), Tübingen.

Jaspert, B., 1994, Karl Barth - Rudolf Bultmann Briefwechsel 1911-1966, 2. Aufl., Theologischer Verlag, Zürich.

Jüngel, E., 1982a, 'Einführung in Leben und Werk Karl Barths', in E. Jüngel (Hg.) Barth Studien, S. 22-60, Benziger Verlag, Zürich-Köln.

Jüngel, E., 1982b, 'Karl Barth', in Barth-Studien, S. 15-21, Benziger Verlag, Zürich-Köln.

Korsch, D., 2016a, 'Aufgabe der Theologie', in M. Beintker (Hg.), Barth Handbuch, S. 276-282, J.C.B. Mohr (Paul Siebeck), Tübingen.

Korsch, D., 2016b, 'Wirkung und Rezeption. In den 1920er Jahren', in M. Beintker (Hg.), Barth Handbuch, S. 424-430, J.C.B. Mohr (Paul Siebeck), Tübingen.

Körtner, U.H.J., 2016, 'Wirkung und Rezeption. In der Blütezeit der Theologie Bultmanns', in M. Beintker (Hg.), Barth Handbuch, S. 444-451, J.C.B. Mohr (Paul Siebeck), Tübingen.

Maurer, E., 2016 'Sprache bei Barth', in M. Beintker (Hg.), Barth Handbuch, S. 165-171, J.C.B. Mohr (Paul Siebeck), Tübingen.

McCormack, B.L., 2016, 'Dogmatische Werke', in M. Beintker (Hg.), Barth Handbuch, S. 247-251, J.C.B. Mohr (Paul Siebeck), Tübingen.

Pannenberg, W., 1958, 'Dialektische Theologie', in K. Galling (Hg.), Die Religion Geschichte und Gegenwart, Handwörterbuch für Theologie und Religionswissenschaft, 3. Aufl., J.C.B. Mohr (Paul Siebeck), Tübingen, 2. Bd., S. Religionsw $168-174$.

Pfleiderer, G., 2016, 'Barth und die liberale Theologie', in M. Beintker (Hg.), Barth Handbuch, S. 59-64, J.C.B. Mohr (Paul Siebeck), Tübingen.

Smend, R., 2016, 'Akademischer Lehrer', in M. Beintker (Hg.), Barth Handbuch, S. $31-$ 37, J.C.B. Mohr (Paul Siebeck), Tübingen.

Stoevesandt, H., 2016, 'Charlotte von Kirschbaum', in M. Beintker (Hg.), Barth Handbuch, S. 54-58, J.C.B. Mohr (Paul Siebeck), Tübingen.

Van der Kooi, C., 2016a, 'Erster Römerbrief', in M. Beintker (Hg.), Barth Handbuch, S. 189-195, J.C.B. Mohr (Paul Siebeck), Tübingen.

Van der Kooi, C., 2016b, 'Zweiter Römerbrief', in M. Beintker (Hg.), Barth Handbuch, S. 195-200, J.C.B. Mohr (Paul Siebeck), Tübingen.

Van der Kooi, C., 2016c, 'Wirkung und Rezeption. Am Ende des 20. Jahrhunderts', in M. Beintker (Hg.), Barth Handbuch, S. 457-464, J.C.B. Mohr (Paul Siebeck), Tübingen.

Weber, O., 1967, Karl Barths Kirchliche Dogmatik, 6. Aufl., Neukichener Verlag, Neukirchen-Vluyn.

Zellweger, B., 2017, Karl Barth. Biography, The Centre for Bath Studies at Princeton Theological Seminary, viewed 31 Maart 2017, from http://barth.ptsem.edu/karlbarth/biography

Zocher, P., 2016, 'Wirkung und Rezeption. In der Kriegs-und Nachkriegszeit', in M Beintker (Hg.), Barth Handbuch, S. 437-444, J.C.B. Mohr (Paul Siebeck), Tübingen 